\title{
Evasión de la respuesta inmune por virus herpes simplex
}

\author{
Angello R. Retamal-Díaz, Paula A. Suazo, Ignacio Garrido, Alexis M. Kalergis y Pablo A. González
}

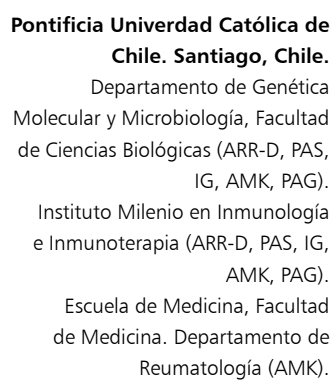

Los autores de este trabajo declaran

no tener conflictos de interés.

El trabajo realizado recibe apoyo

de los proyectos FONDECYT $n^{\circ}$ 1140011, FONDECYT n' 11075060

FONDECYT no 1100926 y el Instituto Milenio en Inmunología e Inmunoterapia (n ${ }^{\circ}$ P09/016-F). ARD es becario CONICYT. AMK es Chaire

De La Région Pays De La Loire, Chercheur Etranger d'Excellence.

Recibido: 18 de marzo de 2014 Aceptado: 2 de noviembre de 2014

Correspondencia a: Pablo González pagonzalez@bio.puc.c

\section{Introducción}

os virus herpes simplex 1 y 2 (VHS-1, VHH-1 y VHS-2, VHH-2) son herpesvirus de la familia Herpesviridae, grupo al cual pertenecen otros virus que infectan con una alta prevalencia a humanos, tales como varicela zóster (VZV, VHH-3), Epstein Barr (VEB, $\mathrm{VHH}-4)$, citomegalovirus (CMV, VHH-5), virus herpes humano 6 (VHH-6), virus herpes humano 7 (VHH-7) y el virus asociado al sarcoma de Kaposi (VHH-8).

Actualmente, se estima que hasta dos tercios de la población mundial está infectada con VHS-1 y que 500 millones de individuos presentan una infección con VHS-2 en el mundo ${ }^{1-4}$. Mientras que VHS-1 es la primera causa de ceguera por infección en el mundo, VHS-2 es la primera de úlceras genitales y recurre frecuentemente con episodios clínicos y sub-clínicos ${ }^{5-9}$. Cuando son transmitidos en forma perinatal, los VHS pueden causar importantes secuelas y mortalidad infantil, incluso con tratamiento antiviral ${ }^{7,10,11}$. Actualmente existe evidencia que asocia la infección de VHS-2 con un incremento significativo en la adquisición $\mathrm{y}$ transmisión del virus de la inmunodeficiencia humana (VIH). (Para una revisión detallada sobre este tópico, los autores recomiendan revisar Freeman y cols. ${ }^{12-14}$ ). La prevalencia de VHS-2 varía considerablemente en el mundo fluctuando entre $8,4 \%$ para Japón y $70 \%$ para África sub-Sahariana, una región donde la prevalencia de VIH es epidémica ${ }^{15,16}$. En los E.U.A., la prevalencia de VHS-2 es aproximadamente de $16 \%$ de acuerdo a datos obtenidos de la encuesta nacional de salud y nutrición
1999-2010 (National Health and Nutrition Examination Survey 1999-2010) ${ }^{17}$. En Chile, estudios realizados entre 1984 y 1986 detectaron la presencia de VHS-2 en 2-3\% de muestras ginecológicas obtenidas de estudiantes de la clínica ginecológica del Servicio Médico y Dental de Alumnos de la Universidad de Chile (n: 635) ${ }^{18}$. Ya que este estudio evaluó presencia de virus y no serología, es esperable que la prevalencia del virus sea considerablemente mayor a lo observado, además de que el diagnóstico realizado mediante cultivo viral es significativamente menos sensible al realizado mediante la RPC ${ }^{19}$. Otro estudio, realizado en el año 2004, observó una seroprevalencia de VHS-2 igual a 43\% utilizando doscientas muestras consecutivas obtenidas desde dos centros de referencia para enfermedades de transmisión sexual, confirmándose además en este estudio, una fuerte asociación entre VHS-2 y $\mathrm{VIH}^{20}$. Datos epidemiológicos recientes para algunos países de la región indican prevalencias de $13,5 \%$ para Perú (n: 9.746) ${ }^{21}$ y $11 \%$ para Brasil (n: 13.986$)^{22}$ para la población general. No obstante, algunos estudios sugieren valores significativamente mayores para este último ${ }^{23,24}$.

Un aspecto importante de VHS-2, es su capacidad de establecer latencia en las neuronas del hospedero, además de evadir la respuesta inmune. Con ello, el virus es capaz de establecer una infección persistente latente con posibilidades de recurrencias, clínicas o sub-clínicas. Aquí, revisamos la literatura en torno a las propiedades desarrolladas por VHS-2 y su especie cercana VHS-1 para persistir en el hospedero, con el fin de identificar nuevas estrategias para contrarrestar sus efectos nocivos. 


\section{Estructura, composición y ciclo replicativo de los virus herpes simplex}

Son virus envueltos, cuyo material genético es de tipo ADN de doble hebra lineal, con tamaños aproximados de $\sim 150.000$ pares de bases y que codifican sobre 70 genes $^{25}$. Este material genético se encuentra empaquetado en una cápside icosaédrica de $125 \mathrm{~nm}$ de diámetro ${ }^{26}$, y recubierta por un tegumento compuesto por $\sim 20$ proteínas virales ${ }^{26,27}$. El tegumento, a su vez, está recubierto por una bicapa lipídica desde la cual protruyen glicoproteínas virales hacia la superficie del virión. Hasta la fecha, se han descrito 11 glicoproteínas virales de superficie, dentro de las cuales nueve a 10 participarían en el ciclo replicativo de estos virus (Figura 1) $)^{28,29}$.

El ciclo infectivo de los VHS comienza con la unión del virus a la membrana de la célula hospedera y la fusión del virión con ésta. Estos pasos están mediados principalmente por cuatro glicoproteínas virales $(\mathrm{gB}, \mathrm{gD}, \mathrm{gH}$ y $\mathrm{gL}$, además de $\mathrm{gC}$ para VHS-1), dos de las cuales entran en contacto directo con receptores específicos presentes en la célula blanco para VHS-2 (tres en el caso de VHS1) y que luego desencadenan la fusión del virus ${ }^{30,31}$. El primer paso es la unión de $\mathrm{gB}$ a proteoglicanos de heparán sulfato (HSPG) en la superficie de la célula hospedera ${ }^{32}$. $\mathrm{El}$ rol de esta proteína puede ser sustituida por $\mathrm{gC}$ en VHS-1 ${ }^{33}$. El siguiente paso, consiste en la interacción específica de $\mathrm{gD}$ con uno de sus dos receptores principales: nectina-1 (PVRL1; poliovirus receptor-related 1) o HVEM (herpesvirus entry mediator, TNFRSF14) (Figura 1), permitiendo un mejor anclaje del virión a la superficie de la célula blanco y la activación de las otras dos glicoproteínas virales de superficie necesarias para activar el proceso de fusión de membranas ( $\mathrm{gH} \mathrm{y} \mathrm{gL})^{34,35}$. Cabe destacar que mientras nectina-1 se expresa de forma ubicua en el hospedero y juega un rol estructural en las uniones adherentes de células epiteliales, así como en la adhesión celular de algunas sinapsis neuronales, HVEM se expresa preferentemente en células inmunes, tales como linfocitos $\mathrm{T}^{36,37}$. La interacción de $\mathrm{gD}$ con cualquiera de estos dos receptores induce modificaciones estructurales en $\mathrm{gD}$ que a su vez conducen a la activación del complejo $\mathrm{gH} / \mathrm{gL}$ en la superficie viral promoviendo la capacidad de fusión de $\mathrm{gB}^{38,39}$.

Luego de la fusión de la membrana viral con la membrana de la célula blanco, proteínas del tegumento dirigen la cápside viral hacia el núcleo de la célula hospedero a través de microtúbulos (Figura 1) ${ }^{26,27}$. Aquí, el ADN viral es inyectado al núcleo a través de poros nucleares y el VHS inicia la expresión secuencial de sus genes comenzando con la transcripción y traducción de genes virales inmediatamente tempranos (immediate early o alfa). Los productos de estos genes juegan roles importantes en el control de la célula infectada e inhiben algunos mecanismos anti-virales tempranos de las células ${ }^{40}$. Posteriormente, le siguen la expresión de genes tempranos (early, o beta) involucrados en la replicación del material genético del virus, como así también en pasos regulatorios de éste ${ }^{41}$. Durante este proceso, el material genético del virus es replicado a través de un intermediario circular transitorio conocida como rolling circle, el que se encuentra regulado por la actividad de ICP0 (infected cell protein 0); el genoma lineal resultante es luego encapsidado en el núcleo de la célula infectada ${ }^{42}$. Finalmente, el virus promueve la transcripción y traducción de genes que se expresan más tardíamente y se denominan tardios tempranos (early late o $\gamma$-1); estos genes están involucrados principalmente en la expresión de proteínas más bien estructurales del virión ${ }^{43}$. Dentro de estos genes

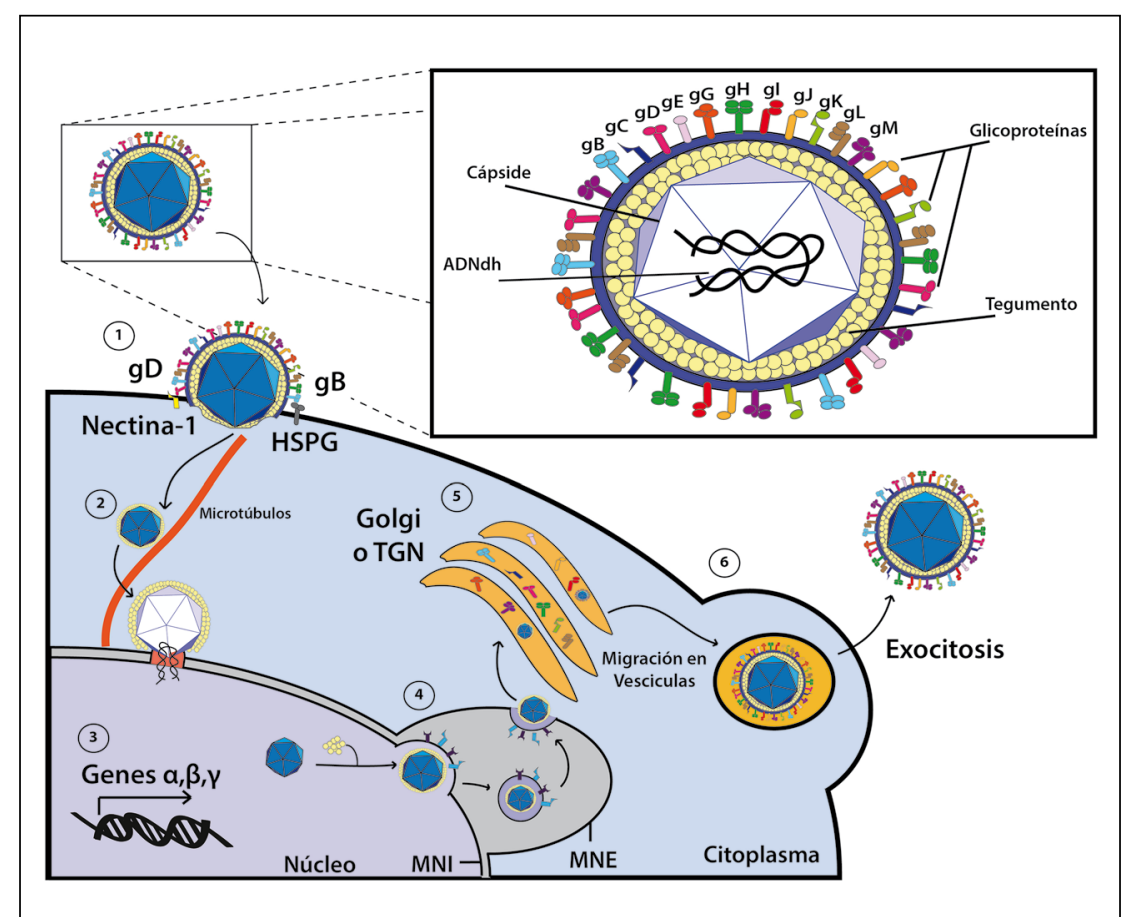

Figura 1. Estructura del VHS y ciclo replicativo de VHS. La infección de una célula blanco es un proceso que involucra al menos cuatro glicoproteínas virales en la superficie del virión. (1) La glicoproteína B (gB) une proteoglicanos de heparán sulfato (HSPG) en la superficie celular. Para VHS-1, la glicoproteína gC también participa en este proceso. Luego, gD une nectina-1 o HVEM en la superficie celular desencadenando la activación del complejo $\mathrm{gH} / \mathrm{gL}$ y la fusión de las membranas del virus y la célula por gB; (2) Dentro de la célula, la cápside viral es transportada al núcleo de la célula mediante la interacción de proteínas del tegumento con microtúbulos; (3) Una vez en el núcleo, los genes virales se expresan secuencialmente con la transcripción de genes inmediatamente tempranos $(\alpha)$, tempranos $(\beta)$ y tardíos $(\gamma)$; (4) La producción de virus a su vez requiere la replicación del material genético viral el cual es encapsidado en el núcleo y recubierto parcialmente por proteínas del tegumento que median la salida de la cápside hacia el espacio perinuclear a través la membrana nuclear interna (MNI) y la membrana nuclear externa (MNE); (5) Esta luego es liberada al citoplasma donde es re-invaginado en al aparato de Golgi donde adquiere sus glicoproteínas de la superficie; (6) Finalmente, el virión abandona la célula por exocitosis. 
expresados tardíamente se han descrito genes aún más tardíos, denominados simplemente tardíos (late o $\gamma-2)^{44}$

El ensamblaje de la cápside viral de VHS con el tegumento y glicoproteínas de superficie del virión en células infectadas involucra múltiples pasos. En este proceso, la cápside es secuencialmente envuelta y desenvuelta en membranas del núcleo hasta la superficie celular, pasando por compartimentos celulares internos tales como espacio perinuclear, citoplasma y aparato de Golgi ${ }^{45,46}$. En la actualidad, se han postulado varios modelos para la salida de VHS desde el interior de células infectadas ${ }^{46}$. Uno de estos modelos postula que la cápside, recubierta con algunas proteínas del tegumento, saldría del núcleo mediante un proceso de envoltura y desenvoltura a través de las membranas internas (MNI) y externas (MNE) del núcleo ${ }^{47}$. En este proceso, la cápside sería envuelta para ingresar al espacio perinuclear y luego desenvuelta, mediante fusión de las membranas lipídicas, para entrar al citoplasma celular ${ }^{48}$. En el citoplasma, la cápside sería recubierta con más proteínas del tegumento para ingresar al aparato de Golgi ${ }^{49}$. En este proceso, la cápside sería envuelta nuevamente, pero esta vez hacia el aparato de Golgi para adquirir su manto lipídico y glicoproteínas de superficie, formando así un virión infectante. Este virión luego es transportado a través de la vía trans-Golgi (transGolgi network; TGN) a la superficie celular en vesículas donde es liberado al medio extracelular (Figura 1).

La liberación de viriones al medio extracelular es un proceso común para la diseminación de virus en general. Los VHS se caracterizan además por diseminarse a través de interacciones célula-célula adyacentes. Este proceso involucra el direccionamiento de componentes virales a la interfase de células que interactúan entre sí y es utilizado tanto para la propagación del virus entre células epiteliales, como para la infección de células inmunes como linfocitos $\mathrm{T}^{50,51}$. En efecto, las células $\mathrm{T}$ no se infectan con virus libre y sólo pueden serlo a través de otras células infectadas con virus herpes simplex, como fibroblastos $^{51}$. Este proceso es denominado sinapsis virológica. Debido a que la distancia entre una célula infectada y una no-infectada es pequeña, la infección celular por esta vía permitirá al virus evadir los efectos de moléculas inmunes solubles, tales como el sistema del complemento y anticuerpos neutralizantes ${ }^{52,53}$. La ventaja de utilizar mecanismos de infección célula-célula es consistente con el hecho de que títulos elevados de anticuerpos contra VHS-2 no se correlacionan necesariamente con una menor gravedad de la enfermedad causada por este virus ${ }^{54}$. La identificación de los procesos moleculares utilizados por VHS para infectar células blanco ha contribuido a entender mejor por qué el hospedero es incapaz de eliminar estos virus por completo del organismo y debiese contribuir al futuro diseño de estrategias que apuntan a proteger y tratar infecciones con VHS.

\section{Latencia y reactivación de virus herpes simplex}

Los virus herpes simplex son neurotrópicos y pueden permanecer de manera latente en células neuronales de los ganglios trigémino (infección oro-facial) y sacro (infección genital) ${ }^{55,56}$. La infección de neuronas con virus simplex ocurre luego de que células epiteliales infectadas con VHS interactúan con los terminales nerviosos de neuronas que inervan los sitios de infección. Una vez que el virus entra en contacto con los terminales neuronales, éste migra retrógradamente por el axón hasta el soma neuronal donde reside de forma latente hasta su reactivación ${ }^{57,58}$. En el núcleo, el genoma viral permanece en forma episomal (no se integra en el genoma del hospedero $)^{59,60}$. El estado de latencia viral se caracteriza por una represión importante de la transcripción de genes virales, salvo para un gen particular el que está asociado a la latencia viral y se ha denominado LAT (latency associated transcript $)^{61}$. Este transcrito viral no-codificante (no codifica proteínas), es procesado en ARN pequeños (micro-ARNs, miARNs) que regulan negativamente la expresión de genes virales inmediatamente tempranos $(\alpha)$ esenciales para el desencadenamiento de la transcripción y traducción de genes tempranos $(\beta)$ y tardios $(\gamma)^{62}$. A través de este mecanismo relativamente simple, el virus es capaz de reprimir la expresión de un sinnúmero de genes virales involucrados en la replicación del genoma y síntesis de elementos estructurales del virión. Este estado silente, caracterizado por una expresión prácticamente nula de proteínas virales, evita que antígenos del microorganismo sean presentadas o reconocidas por el sistema inmune del hospedero. Con ello, el virus impide el desarrollo de una respuesta anti-viral contra neuronas infectadas. Por otro lado, aparte de la acción de LAT se ha propuesto que mecanismos epigenéticos podrían regular y modular los estadios líticos y latentes del virus en células infectadas. Por ejemplo, en neuronas VHS-1 promovería que el genoma viral se encontrase como heterocromatina en los promotores de los genes líticos con el fin de silenciar y reducir la expresión de genes virales ${ }^{63}$. Por el contrario, en células epiteliales donde el virus presenta un ciclo lítico, VHS-1 promovería que su genoma se encontrase como eucromatina a través del reclutamiento de factores de remodelación que promoverían la transcripción activa de genes conducentes a la formación de viriones ${ }^{64,65}$. Algunos de estos procesos estarían mediados por la proteína viral ICP0; no obstante, aún no se conoce con exactitud los mecanismos por los cuales esta proteína regularía uno u otro estado del genoma viral dentro de la células infectada ${ }^{66,67}$.

Si bien no se conocen los eventos moleculares íntimos que conducen a la reactivación del virus en neuronas, algunos desencadenantes de la activación viral han sido identificados. Algunos de estos factores modulan 
negativamente la expresión de LAT y por consiguiente promueven la transcripción y traducción de genes virales inmediatamente tempranos, tempranos y tardios que conducen a la reactivación del virus y síntesis de viriones. Se ha descubierto que varios de estos estímulos activadores están relacionados con injuria celular. Por ejemplo, condiciones de hipoxia celular e inducción de apoptosis disminuyen significativamente los niveles de expresión de LAT de VHS-1 en neuronas, aumentando significativamente la expresión de genes virales que promueven la síntesis de viriones ${ }^{68,69}$. Con ello, VHS serían capaces de "sensar" la viabilidad de las células que infectan, para promover su activación y puesta en marcha de la replicación antes de que estas células mueran. Una vez iniciada la expresión de genes virales tempranos y tardíos en neuronas, se formará la cápside viral que migra de forma anterógrada desde el soma celular hasta el terminal nervioso, por el axón, hasta el lugar donde ocurrió la infección inicial. La liberación de partículas en este sitio promoverá la infección de nuevas células epiteliales con la subsiguiente diseminación del virus en el tejido circundante, promoviendo la generación de nuevos focos de infección e ingreso del virus a nuevos terminales nerviosos, repitiendo así el ciclo infectante y el establecimiento continuo de latencia en el hospedero ${ }^{24}$.

Otro gatillante que promueve la reactivación del virus desde los sitios de latencia es la radiación ultra-violeta sobre la piel, posiblemente por inducción de injuria celular en los terminales nerviosos de neuronas infectadas con $\mathrm{VHS}^{70}$. Se ha asociado también a la reactivación de VHS el estrés, la hipotermia, la hipertermia y fatiga ${ }^{71,72}$. Por otro lado, la reactivación de VHS-2 en los genitales se ha relacionado en parte con el ciclo hormonal en mujeres, un factor que no parece afectar la reactivación de VHS-1 en la región oro-facial ${ }^{73}$. Además, VHS-1 puede reactivarse en respuesta a fármacos immunosupresores que modulan negativamente la respuesta inmune y la capacidad de ésta para reprimir recurrencias virales ${ }^{71}$.

Las reactivaciones con VHS-2 pueden resultar evidentes en individuos con manifestaciones clínicas recurrentes; sin embargo, hasta $75 \%$ de los individuos infectados con este virus presentan cuadros asintomáticos, esto es, no manifiestan lesiones ${ }^{74-76}$. Sorprendentemente, $70 \%$ de los individuos infectados asintomáticos experimenta reactivaciones virales que liberan partículas virales infectantes tan frecuentemente como aquellos individuos sintomáticos ${ }^{73}$. Se ha estimado que los individuos infectados asintomáticamente con VHS-2 pueden liberar virus infectante hasta 3 a $5 \%$ de los días evaluados, medido por cultivo viral, lo que alcanza hasta $28 \%$ utilizando técnicas de $\mathrm{RPC}^{19}$. Ello significa que un individuo asintomático infectado con VHS-2 podría diseminar virus hasta 102 días al año sin saberlo. Con ello, VHS-2 goza de una capacidad única para resguardarse y propagarse en la población.

Una interrogante importante con respecto a la distintas tasas de recurrencia de VHS-1 y VHS-2 (VHS-1 recurre más en el área oro-facial, mientras que VHS-2 recurre más en el área genital), es la capacidad de estos virus de residir latentemente en neuronas asociadas a estos si$\operatorname{tios}^{7,77-79}$. Si bien un estudio sugiere que ambos virus tienen capacidades similares de residir en los ganglios trigémino y dorsal, otro estudio sugiere que VHS-1 abunda significativamente más en el ganglio trigémino que VHS- $2^{55,56}$. Ello lleva a postular que la mayor recurrencia de uno $u$ otro virus en una región determinada podría deberse a diferencias en la capacidad de estos virus de alojarse en estos sitios neuronales. Consistente con esta noción, se ha descrito que VHS-1 y VHS-2 mantendrían latencia en distintos tipos de neuronas. Mientras que VHS-1 infectaría preferencialmente neuronas con el marcador molecular A5, VHS-2 lo haría en neuronas KH10 positivas ${ }^{80}$. Otra alternativa, es que factores locales asociados a cada uno de estos ganglios neuronales, y aún no identificados, sean claves en la modulación de la reactivación viral.

\section{Evasión de la respuesta inmune innata}

\section{El virus herpes simplex interfiere con la respuesta antiviral mediada por interferón}

Los VHS codifican determinantes moleculares que modulan negativamente la respuesta antiviral del hospedero e interfieren con elementos de la respuesta inmune innata. Con ello, los VHS son capaces de recurrir repetidamente en individuos inmunocompetentes, y más aún en individuos inmunosuprimidos.

Un modo por el cual las células diana del virus limitan y controlan infecciones virales es a través de respuestas celulares antivirales, desencadenadas en presencia de patrones moleculares asociados a patógenos (pathogen associated molecular patterns, PAMPs) ${ }^{81-84}$. Este proceso, mediado en parte por receptores de tipo Toll (Toll likereceptors; TLRs), conlleva a la activación de vías de señalización intracelulares que inducen la expresión y secreción de moléculas que limitan la replicación viral, alertan células vecinas y activan al sistema inmune ${ }^{85-89}$. Para evitar la activación de estas vías de señalización, la proteína estructural vhs (virion host shutoff) de VHS promueven la degradación de ARN mensajero del hospedero mediante su actividad ribonucleasa, disminuyendo así la traducción de elementos celulares anti-virales ${ }^{90}$. Si bien ambas proteínas vhs de VHS-1 y VHS-2 poseen importante homología; vhs de VHS-2 es hasta 40 veces más potente que vhs de VHS-1 ${ }^{91}$. Además, se ha descrito que vhs de VHS-2 puede suprimir directamente la detección de ARN doble hebra viral por parte de células infectadas y las vías de interferones de tipo I (IFN-I) ${ }^{92}$ (Figura 2, panel izquierdo). Una disminuida capacidad de detectar VHS y menor expresión de moléculas antivirales incrementarían 


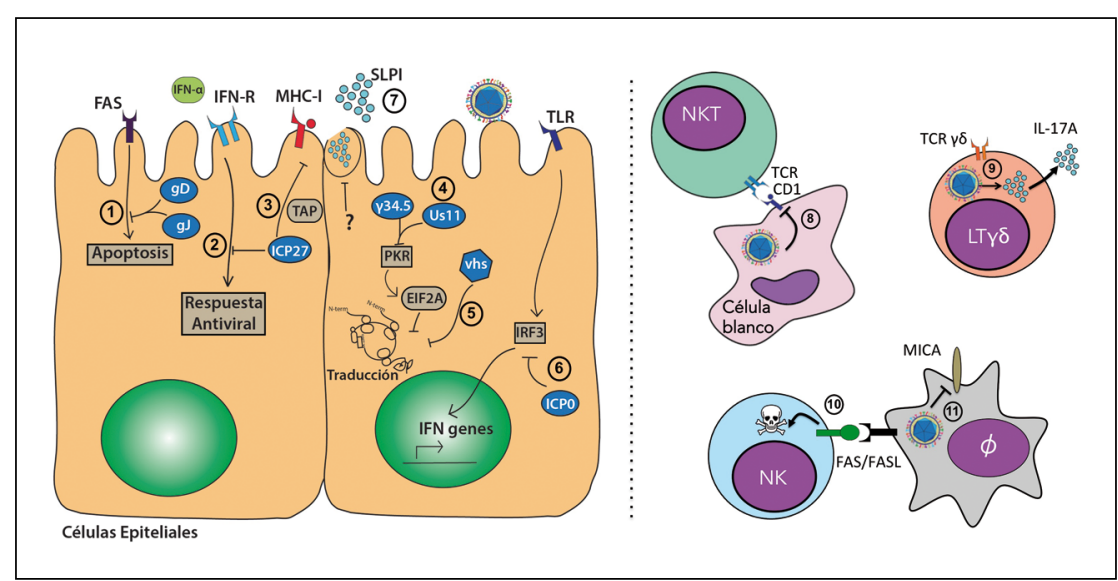

Figura 2. Evasión de la respuesta inmune innata. Panel izquierdo: Numerosas proteínas y glicoproteínas de VHS modulan negativamente tanto células epiteliales como células inmunes innatas. (1) Las glicoproteínas virales gD y gJ inhiben vías de señalización que conducen a la apoptosis celular mediada por Fas-FasL; (2 y 3) ICP27 en cambio interfiere con la vía de señalización antiviral activada por interferones (IFNR: receptor de interferón) e inhibe la expresión de MHC-I de superficie en las células infectadas a través del bloqueo de la proteína TAP; (4) Las proteínas $\gamma 34.5$ y Us 11 inhiben la activación de la proteína quinasa R (PKR), la cual comúnmente fosforila al factor de inicio de la traducción 2A (elF2A) para bloquear la traducción de proteínas en células infectadas; (5) La proteína viral vhs también inhibe la traducción de proteínas del hospedero, a través de la degradación de ARN mensajeros; (6) La proteína temprana ICPO bloquea el factor de transcripción IRF3, el cual es necesario para la expresión de interferones y la respuesta anti-viral de la célula; (7) Finalmente, VHS-2 bloquea la síntesis y secreción de SLPI por un mecanismo aún desconocido. Panel derecho: (8) VHS inhibe la presentación de CD1d en la superficie de células infectadas mediante el re-direccionamiento de estas moléculas a compartimentos intracelulares afectando negativamente la función antiviral de células Natural Killer T (NKT); (9) VHS infecta células inmunes innatas como linfocitos T $\gamma \delta$ (LT $\gamma \delta$ ) e induce la expresión de la citoquina pro-inflamatoria IL-17A por parte de estas células; (10) Por otro lado, VHS induce la apoptosis de células natural killer (NK) a través de la interacción con macrófagos infectados con VHS y receptores Fas/FasL; (11) Además, VHS disminuye la expresión de ligandos activadores de células NK en células infectadas, tales como MICA, impidiendo así la actividad efectora de células NK. MHC-I: complejo mayor de histocompatibilidad de clase I; SLPI: inhibidor de proteasa secretor de leucocitos; TAP: transportador asociado con el procesamiento antigénico; TLR: receptor tipo Toll; TCR: receptor de célula T; MICA: MHC class I polypeptide-related sequence $A ;$; : macrófagos. La calavera indica apoptosis. La distinción de mecanismos de evasión propios a VHS-1 o VHS-2 se encuentra detallado en el texto imiquimod, un activador de la respuesta inmune innata y de interferones, es efectivo para el tratamiento de VHS-1 y VHS-2, incluso contra cepas resistentes a aciclovir, en pacientes inmunocomprometidos ${ }^{96-98}$. Además, múltiples estudios en animales han demostrado que la activación de TLRs con los agonistas poly (I:C $)^{81}$, imiquimod ${ }^{82} \mathrm{o}$ CpG-ODN ${ }^{83,84}$ protegen significativamente frente a una infección genital con VHS-2 a través de una disminución en la secreción vaginal del virus, demostrando así el importante rol que tienen los interferones de tipo I en el control de la infección viral.

Por otro lado, la molécula antiviral PKR (protein kinase $R$ ) del hospedero está involucrada en la fosforilación del factor de inicio de la traducción eIF2A para inhibir la traducción de mensajeros virales luego de infecciones celulares. Se ha demostrado que esta proteína juega un rol importante en el control de la replicación de VHS, tanto in vivo como in vitro ${ }^{99,100}$. Para evadir la función de esta proteína del hospedero, los genes tardíos $\gamma 34.5$ y $\mathrm{U}_{\mathrm{S}} 11 \mathrm{de}$ VHS-1 inhiben la actividad de PKR ${ }^{101,102}$ (Figura 2, panel izquierdo). Por otro lado, VHS-2 es capaz de reducir la expresión de moléculas anti-virales como el inhibidor de proteasa secretor de leucocitos (SLPI) por parte de células infectadas, al cual se le reconoce la capacidad de reducir la infectividad de VHS-2 y VIH in vitro ${ }^{103}$. La disminución en la expresión de SLPI promueve además el incremento en la secreción de citoquinas pro-inflamatorias, las cuales se asocian con un daño exacerbado del tejido infectado (Figura 2, panel izquierdo) ${ }^{103}$.

\section{Modulación de apoptosis celular por proteínas de virus herpes simplex}

Otra manera por la cual células infectadas con virus evitan la diseminación del patógeno en el tejido es a través de muerte celular programada: apoptosis ${ }^{104}$. Para contrarrestar este proceso, VHS codifican determinantes que bloquean los procesos conducentes a apoptosis, sean estos intrínsecos o extrínsecos, tales como aquellos mediadas por gránulos citotóxicos o por Fas/FasL (CD95/CD95L) en células epiteliales infectadas ${ }^{105-107}$. Este proceso antiapoptótico estaría mediado en VHS-1 por glicoproteínas virales como gJ y gD ${ }^{107}$. Por otro lado, ICP10PK y UL14 de VHS-2 prevendrían procesos de apoptosis celular desencadenados luego de la infección de neuronas y células epiteliales ${ }^{108,109}$.

\section{VHS interfiere con la función del complemento}

Se ha descrito que, tanto VHS-1 como VHS-2 modulan negativamente la actividad de componentes inmunes innatos a través de sus glicoproteínas $\mathrm{C}(\mathrm{gC})$ de superficie, las que poseen capacidad para contrarrestar el efecto del complemento del hospedero en la superficie viral $^{53}$. gC interfiere específicamente con la función de C5 del complemento, un elemento clave para la actividad 
antimicrobiana de este componente inmune ${ }^{53,110}$. Con ello, estos virus impiden que se forme el complejo de ataque a membranas en la envoltura del virión, lo que le permite incrementar su viabilidad cuando se encuentran en el ambiente extracelular.

\section{El virus herpes simplex modula la actividad de células NKT y NK}

Otro mecanismo molecular desarrollado por virus herpes simplex para evadir la respuesta inmune innata es mediante la modulación de la función de células natural killer T (NKT). Estas células del sistema inmune innato reconocen moléculas lipídicas polares, propias del hospedero, denominadas CD1d, las que poseen similitudes estructurales con moléculas de histocompatibilidad de clase I (MHC-I) ${ }^{111}$ (Figura 2, panel derecho). Recientemente se ha demostrado que VHS-1 es capaz de impedir la presentación de CD1d en la superficie de células infectadas, mediante el re-direccionamiento de estas moléculas a compartimentos intracelulares ${ }^{12,113}$. Con ello, el virus es capaz de evadir la presentación del ligando a células NKT evitando así la actividad citotóxica de estas células. Por otro lado, se ha descrito en el modelo murino de infección para VHS-2, que este virus puede infectar células inmunes innatas como células $\mathrm{T}$ $\gamma \delta$, para las cuales aún no se conocen claramente los receptores reconocidos por estas células ${ }^{114}$. VHS-2 modula la actividad de estas células induciendo la expresión de la citoquina pro-inflamatoria IL-17A, la cual se cree que incrementa la patología observada en el sitio de infección (Figura 2, panel derecho) ${ }^{115}$. También se ha demostrado que tanto VHS-1 como VHS-2 inducen la apoptosis de células natural killer (NK), especializadas en reconocer células que expresan bajos niveles de MHC-I en la superficie, tales como células infectadas con VHS-2 (ver más abajo). La apoptosis de células NK ocurriría a través de la interacción con macrófagos infectados y los receptores Fas/FasL ${ }^{116}$. Además de disminuir la expresión de MHC-I en la superficie de células infectadas, VHS-1 y -2 disminuyen también la expresión de ligandos activadores de células NK en estas células tales como MICA ( $M H C$ class I polypeptide-related sequence $A$ ), impidiendo así la actividad efectora de estas células ${ }^{117,118}$ (Figura 2, panel derecho). No obstante, cabe destacar que el rol de células NK en el control de VHS aún no está del todo claro, ya que algunos estudios le atribuyen distinta relevancia durante la infección viral ${ }^{119,120}$.

\section{Evasión de la respuesta inmune adaptativa}

\section{Evasión de la respuesta inmune humoral}

Además de evadir la respuesta inmune innata, VHS son capaces también de evadir la respuesta inmune adaptativa mediante la interferencia de la función de anticuerpos y células T. En efecto, las glicoproteínas E (gE) de superficie de VHS-1 y VHS-2 poseen la capacidad de interferir con la función efectora de anticuerpos IgG al unirse a la porción invariable de estas moléculas, denominada Fc (fragmento cristalizable) ${ }^{52,121}$. Es más, $\mathrm{gE}$ posee un dominio proteico con homología a receptores del hospedero llamados Fc $\gamma$ Rs, los cuales son expresados en la superficie de células inmunes y median la captura y degradación de microbios opsonizados (complejos antígeno-anticuerpo o complejos inmunes) a través de la unión a la porción Fc de los anticuerpos ${ }^{121-123}$. Con ello, las glicoproteínas $\mathrm{gE}$ de VHS evitarían, tanto la acción del complemento, como la fagocitosis vía receptores Fc $\gamma$ Rs por células inmunes.

\section{VHS interfiere con la función de las células dendríticas}

Por otra parte, las células dendríticas (CDs) son células presentadoras de antígeno claves para la activación y regulación de la respuesta inmune encontrándose en la interfase del sistema inmune innato y el sistema inmune adaptativo $^{124-127}$. Estas células poseen la capacidad de identificar elementos foráneos y experimentar una serie de transformaciones fenotípicas que le confieren capacidad de activar y modular la respuesta de otras células inmunes como células $\mathrm{T}^{124-127}$. Producto del importante rol que juegan las CDs en el establecimiento de la respuesta inmune adaptativa, los patógenos han desarrollado mecanismos moleculares para interferir con la función de estas células $^{125,128-133}$. Una manera eficiente de interferir con la función de CDs es comprometiendo la viabilidad de estas células. Recientemente se ha descrito que VHS-2 es capaz de inducir apoptosis en CDs humanas, impidiendo su capacidad de activar células $\mathrm{T}^{134,135}$. Antes de experimentar apoptosis, CDs infectadas con VHS-2 demuestran además una incapacidad de hacer una transición hacia fenotipos activadores y secretan citoquinas pro-inflamatorias que son liberadas al medio extracelular (Figura 3$)^{135}$. Si bien, no se sabe con certeza la naturaleza y el rol que jugarían estas citoquinas en el control o infección de VHS-2, se ha descrito que estas moléculas son capaces de promover la activación y replicación de VIH desde células infectadas, aumentando así la diseminación de este último en el organismo en individuos infectados por $\mathrm{VIH}^{135}$. Este hallazgo implica relaciones directas entre ambos virus en individuos co-infectados con VHS-2 y VIH. Por otra parte, se ha demostrado que la proteína $\gamma 34.5$ de VHS-1 puede impedir la maduración del autofagosoma de células infectadas, el cual presenta funciones antivirales en algunos tipos celulares como CDs y neuronas ${ }^{136,137}$. Mediante la inhibición de la función del autofagosoma, VHS pueden impedir la presentación de antígenos a linfocitos $\mathrm{T}$, así como su degradación (Figura 3). Sin embargo, el hecho de que VHS-2 puede ser mantenido bajo control en individuos inmunocompetentes infectados con este 


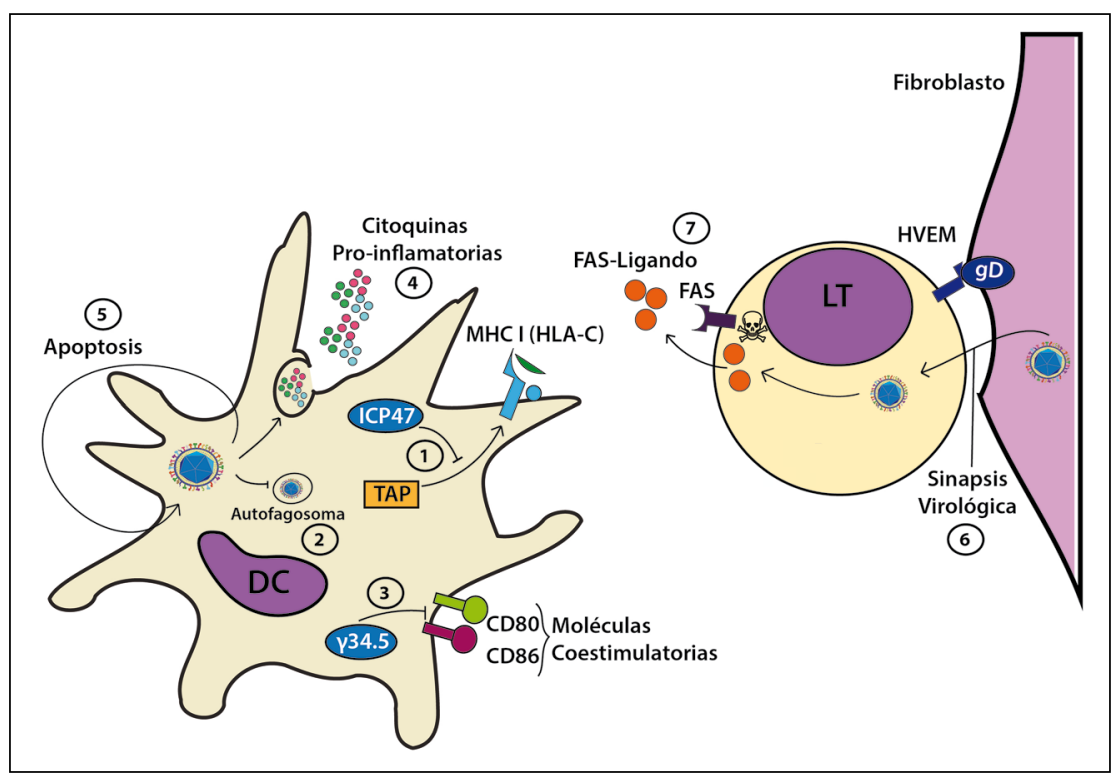

Figura 3. Evasión de la respuesta inmune adaptativa por VHS. (1) En células dendríticas (DC), VHS puede bloquear la presentación de antígenos mediada por moléculas de histocompatibilidad de clase I (MHC-I) alelo HLA-C; (2) Además, en estas células el virus impide su degradación inhibiendo la formación de autofagosomas; (3) VHS puede disminuir la activación de DCs, evidenciado a través de una disminución en la expresión de moléculas co-estimulatorias CD80 y CD86; este proceso es mediado por $\gamma 34.5$. Por otro lado, VHS-2 induce la síntesis y liberación de citoquinas pro-inflamatorias (4) e induce apoptosis en DCs (5); (6) Se ha descrito también que VHS-2 puede infectar linfocitos T (LT) a través de sinapsis virológica mediado por la unión entre HVEM y gD; (7) Una vez que el linfocito T es infectado, el virus promueve la liberación del ligando Fas y la auto-inducción de apoptosis en estas células.TAP: transportador asociado con el procesamiento antigénico;la calavera indica muerte por apoptosis. La distinción de mecanismos de evasión propios a VHS-1 o VHS-2 se encuentra detallado en el texto.

virus sugiere que el hospedero es capaz de desarrollar elementos inmunes contra este virus, si bien esta inmunidad no es esterilizante. Esto se debería en parte a que CDs infectadas con VHS y que se encuentran apoptóticas serían fagocitadas por CDs no-infectadas y presentadas de manera cruzada a linfocitos $T$ vírgenes ${ }^{134}$.

\section{Evasión de la respuesta celular T}

Otro mecanismo por el cual virus herpes simplex interfiere con el establecimiento de una respuesta inmune T anti-viral efectiva, es mediante la interferencia de la presentación de antígenos virales en la superficie de células infectadas. Los VHS poseen la capacidad de interferir, entre otros, con la presentación de antígenos derivados de sus proteínas mediante el bloqueo de moléculas TAP (transporter associated with antigen processing) del hospedero ${ }^{138}$. Las proteínas TAP se encuentran en la interfase del citoplasma y el retículo endoplasmático en la célula y median pasos claves en la transferencia de antígenos desde el citoplasma a moléculas de MHC. La inhibición de la función de proteínas TAP está mediada por las proteínas virales ICP47 de VHS-1 y VHS-2 en células epiteliales infectadas ${ }^{139} \mathrm{y}$ además por la proteína $\mathrm{U}_{\mathrm{s}} 3$ quinasa en VHS-1, la que se ha demostrado también poseer efectos directos en la disminución de MHC-I en la superficie de fibroblastos (Figura 2, panel izquierdo) ${ }^{140}$. Mediante este mecanismo, células infectadas presentarán un menor número de complejos péptido-viral/ MHC (pMHC) en sus superficies, disminuyendo así la presentación de antígenos virales a células T citotóxicas. Si bien células presentadoras de antígenos profesionales son más resistentes a los efectos de ICP47 sobre proteínas TAP que células epiteliales, recientemente se demostró que esta proteína viral puede bloquear de todos modos la expresión de algunos alelos específicos de MHC-I en la superficie de CDs humanas, mediante una interacción directa con HLA-C (Figura 3) ${ }^{141}$. Con ello, CDs infectadas con VHS-2 pasan a ser más susceptibles a la actividad citotóxica de células NK, lo que promueve la eliminación de CDs infectadas con el virus y reduce la disponibilidad de estas células para la presentación de antígenos virales a células $T^{141}$ (Figura 3 ).

Se ha demostrado también que los VHS son capaces también de interferir directamente con la función de células $\mathrm{T}$, independiente de células presentadoras de antígenos. Este proceso estaría mediado por la infección de células T mediante el establecimiento de sinapsis virológica con fibroblastos infectados, como se ha demostrado para VHS-1 y VHS-2 (Figura 3) ${ }^{51}$. Sin embargo, los efectos moduladores de VHS-1 sobre células T se producirían de forma independiente a la síntesis de ADN viral ya que la replicación viral en células $\mathrm{T}$ es limitada ${ }^{142}$. Más aún, se ha observado que la infección de linfocitos T con VHS-2 induce apoptosis en estas células ${ }^{143,144}$. Adicionalmente, se ha observado que linfocitos $\mathrm{T}$ infectados con virus mueren a través de fratricidio, proceso en el cual células T $\mathrm{CD} 8^{+}$ no infectadas con el virus atacan a células $\mathrm{T}$ infectadas a través de Fas/FasL (Figura 3) ${ }^{145}$. VHS son capaces también de modular negativamente la proliferación de células T mediante la acción directa de sus glicoproteínas de superficie como se ha demostrado para gD de VHS-1, incluso en respuesta a estímulos activadores fuertes ${ }^{146}$. Esto sugiere que VHS, particularmente VHS-1, puede modular directamente y de manera negativa vías de señalización intracelulares del receptor de la célula $\mathrm{T}$ ( $T$ cell receptor; TCR) ${ }^{147,148}$.

Aparte de la modulación de linfocitos T CD $4^{+}$y T CD $8^{+}$ efectores, la infección con VHS aumentaría también el número y función de linfocitos $T$ reguladores (Tregs) en individuos infectados, de acuerdo a resultados obtenidos en el modelo de infección murino con VHS-2 (Figura $3)^{149,150}$. Estas Tregs modularían negativamente la respuesta efectora de células T citotóxicas contra VHS-2 ${ }^{149,151}$. Consistente con esta noción, animales vacunados con una cepa atenuada de VHS-1 capaz de generar inmunidad protectora contra VHS-1 y VHS-2, poseen un bajo 
número de linfocitos Tregs luego de un desafío con el virus silvestre ${ }^{152}$. Sin embargo, otro estudio sugiere que la eliminación de Tregs en animales infectados con VHS-2 disminuye la migración temprana de células inmunes al lugar de infección, lo que afectaría negativamente la sobrevida de los ratones infectados ${ }^{153}$. Estas diferencias podrían deberse a las metodologías utilizadas para eliminar las células Treg (anti-CD25 vs toxina pertussis) o bien a la edad de los animales utilizados (neonatos vs. adultos), ya que animales neonatos son más susceptibles a infecciones virales ${ }^{154,155}$. Con ello, el rol de Tregs debe aún ser explorado en mayor profundidad.

\section{Formulaciones profilácticas contra $\mathrm{VHS}-2$}

Debido a su importante asociación con VIH y el carácter recurrente de la patología producida por VHS2 , una vacuna contra este virus es de interés público ${ }^{12-14}$. A pesar de esfuerzos significativos por desarrollar una formulación protectora contra VHS-2, hasta la fecha no existe una vacuna para combatir este virus. Una estrategia ampliamente evaluada desde hace dos décadas se basa principalmente en formulaciones que contienen subunidades proteicas virales combinadas con adyuvantes ${ }^{156}$. Una de estas formulaciones, desarrollada por GlaxoSmithKline contiene la glicoproteína D de VHS-2 y el adyuvante monofosforil lípido A (MPL) y produce, tanto anticuerpos neutralizantes en individuos vacunados, así como células $\mathrm{T} \mathrm{CD} 4^{+157}$. Si bien esta formulación presentó resultados alentadores en fases clínicas tempranas, estudios posteriores fracasaron en demostrar protección significativa contra herpes genital producido por VHS$2^{158,159}$. De manera paradójica, la inmunización con esta formulación protegió contra herpes genital producido por VHS- $1^{159}$. Estos datos sugieren que una protección efectiva contra VHS-2 requeriría una respuesta celular de tipo $\mathrm{T} \mathrm{CD}^{+}$, o bien, títulos mayores de anticuerpos neutralizantes. Alternativamente, estos resultados sugieren que una respuesta inmune protectora contra VHS-2 podría requerir anticuerpos y células $\mathrm{T}$ contra antígenos distintos o adicionales a gD. Con ello, formulaciones inmunogénicas basadas en cepas vivas atenuadas de VHS-2 han vuelto a cobrar interés. Además, la existencia de una vacuna viva atenuada efectiva contra el virus varicela zoster que es segura e inmunogénica, sugiere que una formulación basada en una cepa viva atenuada de VHS-2 podría ser una alternativa viable como vacuna contra este virus ${ }^{160,161}$. Estudios anteriores con una cepa atenuada de VHS-2 incompetente para la replicación (e.g. carente de la glicoproteína $\mathrm{H}, \mathrm{gH}$ ) demostraron que ésta era segura en humanos; sin embargo, no demostró beneficios clínicos contra VHS-2 genital en individuos inmunocompetentes ${ }^{162}$. A pesar de ello, nuevas cepas atenuadas de VHS-2 han sido evaluadas recientemente con resultados alentadores. Una de estas cepas virales presenta una deleción del gen UL39 (ICP10 $\Delta$ PK) y produce una disminución en las recurrencias por VHS-2 en individuos inmunizados ${ }^{163}$. Otras cepas mutantes de VHS- 2 con deleciones en genes virales tales como $I C P 0$, UL5, UL29 y US8, han sido probadas con resultados positivos en el modelo murino y se espera que puedan ser evaluadas prontamente en fases clínicas en humanos. Es importante destacar que algunas de estas cepas atenuadas, como aquella que carece del gen $I C P 0$,confieren en el modelo animal mayores protecciones contra VHS-2 que la formulación vacuna basada en gD probada en humanos ${ }^{164}$. Cepas virales que carecen de genes involucrados en la replicación viral (UL5 y UL29) ${ }^{165,166}$ o en los procesos de entrada y diseminación del virus $(\mathrm{gE})^{167}$ también han sido evaluadas en modelos animales y demostrado ser seguras, inmunogénicas e inducir inmunidad protectora contra la patología por VHS. Actualmente, estudiamos una cepa atenuada de VHS-2 que carece de la glicoproteína gD, la que induce protección contra VHS-2 genital en el modelo murino datos no publicados). Esta cepa produce anticuerpos contra VHS-2 y activa células T CD8+ antivirales.

\section{Notas finales}

Los virus herpes simplex co-existen con humanos desde tiempos remotos, evidenciado en parte, por análisis filogenéticos recientes que relacionan cepas virales de virus herpes simplex con la migración intercontinental del hombre ${ }^{168}$. Esta co-existencia es consecuencia de una batalla constante entre el virus y el hospedero, en la cual ambos han desarrollado mecanismos moleculares para contrarrestar el efecto del otro. La capacidad de VHS de residir de manera silente en neuronas, es sin lugar a duda, clave para la latencia del virus e infección crónica del hospedero, pues esta característica le permite al patógeno mantenerse al margen de una respuesta inmune agresiva y recurrir cuando la inmunidad está debilitada. Además, los VHS han desarrollado múltiples mecanismos moleculares para evadir tanto la respuesta inmune innata como adaptativa y favorecer su persistencia en el hospedero. Sin embargo, resulta relevante indicar que un gran número de cepas atenuadas de VHS-2 desarrolladas hasta la fecha y probadas en modelos animales que confieren protección significativa contra herpes genital, expresan múltiples de los factores de virulencia descritos en esta revisión. Ello propone que la inclusión de estos factores de virulencia en formulaciones inmunogénicas destinadas a la profilaxis contra este virus jugarían roles positivos en la inducción de una respuesta inmune protectora, más que impedirla. Consistente con ello, algunos estudios han demostrado en modelos animales que la vacunación con proteínas virales como gC y gD, las que confieren al virus capacidad de evadir la función efectora de anticuerpos y complemento, así como modular la activación de células 
$\mathrm{T}$, pueden inducir una respuesta inmune protectora contra una infección con VHS-2 ${ }^{169}$. En forma similar, la inclusión de $\mathrm{gE}$ a una formulación que contiene $\mathrm{gC}$ y $\mathrm{gD}$ indujo mayor protección contra infección con VHS-2 lo cual se atribuyó a la inducción de anticuerpos que bloquean la función de gE. En consecuencia, la identificación de factores de virulencia y su inclusión en formulaciones inmunogénicas podría acelerar el desarrollo de vacunas que protegen contra infecciones con virus herpes simplex. Por tanto, resulta importante continuar explorando los mecanismos moleculares por los cuales estos virus evaden la respuesta inmune.

\section{Resumen}

Los virus herpes simplex y humanos co-existen desde decenas de miles de años. Esta prolongada relación se ha traducido en la evolución y selección de determinantes virales para evadir la respuesta inmune y recíprocamente la evolución y selección de componentes inmunes del hospedero para limitar la infección viral y el daño que producen. Actualmente no existen vacunas para evitar la infección de estos virus o terapias que la curen. Los virus herpes simplex son neurotrópicos y permanecen latentes en neuronas de ganglios trigémino y dorsales, reactivándose esporádicamente. La mayoría de las recurrencias por virus herpes simplex son sub-clínicas y por tanto pasan inadvertidas. Aquí discutimos los pasos iniciales de la infección porvirus herpes simplex y los mecanismos moleculares que estos virus han desarrollado para evadir la respuesta inmune innata y adaptativa. Una mejor comprensión de los mecanismos moleculares evolucionados por estos virus para evadir la respuesta inmune del hospedero deberían ayudarnos visualizar nuevas estrategias para desarrollar vacunas y terapias que limiten su infección y diseminación.

\section{Referencias bibliográficas}

1.- Looker K J, Garnett G P, Schmid G P. An estimate of the global prevalence and incidence of herpes simplex virus type 2 infection. Bull World Health Org 2008; 86: 805-12, A.

2.- Schillinger J A, Xu F, Sternberg M R, Armstrong G L, Lee F K, Nahmias A J, et al. National seroprevalence and trends in herpes simplex virus type 1 in the United States, 19761994. Sex Transm Dis 2004; 31: 753-60.

3.- Smith J S, Robinson N J. Age-specific prevalence of infection with herpes simplex virus types 2 and 1: a global review. J Infect Dis 2002; 186 Suppl 1: S3-28.

4.- Chayavichitsilp P, Buckwalter J V, Krakowski A C, Friedlander S F. Herpes simplex. Pediatr Rev 2009; 30: 119-29; quiz 30.

5.- Farooq A V, Shukla D. Herpes simplex epithelial and stromal keratitis: an epidemiologic update. Surv Ophthalmol 2012; 57: 448-62.

6.- Kaye S, Choudhary A. Herpes simplex keratitis. Prog Retin Eye Res 2006; 25: 355-80.

7.- Lafferty W E, Coombs R W, Benedetti J, Critchlow C, Corey L. Recurrences after oral and genital herpes simplex virus infection. Influence of site of infection and viral type. $\mathrm{N}$ Engl J Med 1987; 316: 1444-9.

8.- Mertz K J, Trees D, Levine W C, Lewis J S, Litchfield B, Pettus K S, et al. Etiology of genital ulcers and prevalence of human immunodeficiency virus coinfection in 10 US cities. The Genital Ulcer Disease Surveillance Group. J Infect Dis 1998; 178: 1795-8.

9.- Paz-Bailey G, Rahman M, Chen C, Ballard R, Moffat H J, Kenyon T, et al. Changes in the etiology of sexually transmitted diseases in
Botswana between 1993 and 2002: implications for the clinical management of genital ulcer disease. Clin Infect Dis 2005; 41: 1304-12.

10.- Kimberlin D. Herpes simplex virus, meningitis and encephalitis in neonates. Herpes 2004; 11 Suppl 2: 65A-76A.

11.- Ward K N, Ohrling A, Bryant N J, Bowley J S, Ross E M, Verity C M. Herpes simplex serious neurological disease in young children: incidence and long-term outcome. Arch Dis Child 2012; 97: 162-5.

12.- Freeman E E, Weiss H A, Glynn J R, Cross P L, Whitworth J A, Hayes R J. Herpes simplex virus 2 infection increases HIV acquisition in men and women: systematic review and metaanalysis of longitudinal studies. AIDS 2006; 20 : 73-83.

13.- Gray R H, Wawer M J, Brookmeyer R, Sewankambo N K, Serwadda D, WabwireMangen F, et al. Probability of HIV-1 transmission per coital act in monogamous, heterosexual, HIV-1-discordant couples in Rakai, Uganda. Lancet 2001; 357: 1149-53.

14.- Wald A, Link K. Risk of human immunodeficiency virus infection in herpes simplex virus type 2-seropositive persons: a meta-analysis. J Infect Dis 2002; 185: 45-52.

15.- Paz-Bailey G, Ramaswamy M, Hawkes S J, Geretti A M. Herpes simplex virus type 2: epidemiology and management options in developing countries. Sex Transm Infect 2007; 83: 16-22.

16.- Doi Y, Ninomiya T, Hata J, Yonemoto K, Tanizaki Y, Arima H, et al. Seroprevalence of herpes simplex virus 1 and 2 in a populationbased cohort in Japan. J Epidemiol 2009; 19: 56-62.
17.- Bernstein D I, Bellamy A R, Hook E W 3rd, Levin M J, Wald A, Ewell M G, et al. Epidemiology, clinical presentation, and antibody response to primary infection with herpes simplex virus type 1 and type 2 in young women. Clin Infect Dis 2013; 56: 344-51.

18.- Suárez M, Briones H, Dubinovsky S, Aliaga P, Alarcón G, Diego S D, et al. Infección genital herpética en estudiantes universitarias chilenas. Bol. Oficina Sanit. Panam 1989; 106: 389-95.

19.- Wald A, Corey L, Cone R, Hobson A, Davis G, Zeh J. Frequent genital herpes simplex virus 2 shedding in immunocompetent women. Effect of acyclovir treatment. J Clin Invest 1997; 99: 1092-7.

20.- Martínez M J, Navarrete N, Santander E, Garmendia M L, Gubelin W. Seropervalencia de la infección por virus herpes simplex tipo 2 en pacientes atendidos en centros de referencia de ETS de Santiago. Rev Med Chile 2005; 133 : 302-6.

21.- Carcamo C P, Campos P E, García P J, Hughes J P, Garnett G P, Holmes K K, et al. Prevalences of sexually transmitted infections in young adults and female sex workers in Peru: a national population-based survey. Lancet Infect Dis 2012; 12: 765-73.

22.- Clemens S A, Farhat C K. Seroprevalence of herpes simplex 1-2 antibodies in Brazil. Rev Saude Publica 2010; 44: 726-34.

23.- Cowan F M, French R S, Mayaud P, Gopal R, Robinson N J, de Oliveira S A, et al. Seroepidemiological study of herpes simplex virus types 1 and 2 in Brazil, Estonia, India, Morocco, and Sri Lanka. Sex Transm Infect 2003; 79: 286-90.

24.- Schiffer J T, Corey L. Rapid host immune 
response and viral dynamics in herpes simplex virus-2 infection. Nat Med 2013; 19: 280-90.

25.- Dolan A, Jamieson F E, Cunningham C, Barnett B C, McGeoch D J. The genome sequence of herpes simplex virus type 2. J Virol 1998; 72: 2010-21.

26.- Dohner K, Wolfstein A, Prank U, Echeverri C, Dujardin D, Vallee R, et al. Function of dynein and dynactin in herpes simplex virus capsid transport. Mol Biol Cell 2002; 13: 2795-809.

27.- Granzow H, Klupp B G, Mettenleiter T C. Entry of pseudorabies virus: an immunogold-labeling study. J Virol 2005; 79: 3200-5.

28.- Rajcani J, Vojvodova A. The role of herpes simplex virus glycoproteins in the virus replication cycle. Acta Virol 1998; 42: 103-18.

29.- Akhtar J, Shukla D. Viral entry mechanisms: cellular and viral mediators of herpes simplex virus entry. FEBS J 2009; 276: 7228-36.

30.- Avitabile E, Forghieri C, Campadelli-Fiume G. Cross talk among the glycoproteins involved in herpes simplex virus entry and fusion: the interaction between $\mathrm{gB}$ and $\mathrm{gH} / \mathrm{gL}$ does not necessarily require gD. J Virol 2009; 83: 10752 60 .

31.- Turner A, Bruun B, Minson T, Browne H. Glycoproteins gB, gD, and $\mathrm{gHgL}$ of herpes simplex virus type 1 are necessary and sufficient to mediate membrane fusion in a Cos cell transfection system. J Virol 1998; 72: 873-5.

32.- Atanasiu D, Cairns T M, Whitbeck J C, Saw W T, Rao S, Eisenberg R J, et al. Regulation of herpes simplex virus gB-induced cell-cell fusion by mutant forms of $\mathrm{gH} / \mathrm{gL}$ in the absence of $\mathrm{gD}$ and cellular receptors. MBio 2013; 4 (2). pii: e00046-13. doi: 10.1128/ mBio.00046-13.

33.- Herold B C, WuDunn D, Soltys N, Spear P G. Glycoprotein $\mathrm{C}$ of herpes simplex virus type 1 plays a principal role in the adsorption of virus to cells and in infectivity. J Virol 1991; 65: 1090-8.

34.- Krummenacher C, Baribaud F, Ponce de León M, Baribaud I, Whitbeck JC, Xu R, et al. Comparative usage of herpesvirus entry mediator A and nectin-1 by laboratory strains and clinical isolates of herpes simplex virus. Virology 2004; 322: 286-99.

35.- Lazear E, Whitbeck J C, Zuo Y, Carfí A, Cohen G H, Eisenberg R J, et al. Induction of conformational changes at the $\mathrm{N}$-terminus of herpes simplex virus glycoprotein D upon binding to HVEM and nectin-1. Virology 2014; 448: 185-95.

36.- Matsushima H, Utani A, Endo H, Matsuura H, Kakuta M, Nakamura Y, et al. The expression of nectin- $1 \alpha$ in normal human skin and various skin tumours. Br J Dermatol 2003; 148: 755-62.

37.- Steinberg M W, Huang Y, Wang-Zhu Y, Ware C F, Cheroutre H, Kronenberg M. BTLA interaction with HVEM expressed on $\mathrm{CD}^{+} \mathrm{T}$ cells promotes survival and memory generation in response to a bacterial infection. PLoS One 2013; 8: e77992.

38.- Fusco D, Forghieri C, Campadelli-Fiume G. The pro-fusion domain of herpes simplex virus glycoprotein D (gD) interacts with the gD N terminus and is displaced by soluble forms of viral receptors. Proc Natl Acad Sci U S A 2005; 102: 9323-8.

39.- Krummenacher C, Supekar V M, Whitbeck J C, Lazear E, Connolly S A, Eisenberg R J, et al. Structure of unliganded HSV gD reveals a mechanism for receptor-mediated activation of virus entry. EMBO J 2005; 24: 4144-53.

40.- Silva L, Oh H S, Chang L, Yan Z, Triezenberg S J, Knipe D M. Roles of the nuclear lamina in stable nuclear association and assembly of a herpesviral transactivator complex on viral immediate-early genes. MBio 2012; 3 (1). pii: e00300-11. doi: 10.1128/ mBio.00300-1.

41.- Wu W, Guo Z, Zhang X, Guo L, Liu L, Liao Y, et al. A microRNA encoded by HSV-1 inhibits a cellular transcriptional repressor of viral immediate early and early genes. Sci China Life Sci 2013; 56: 373-83.

42.- Jackson S A, DeLuca N A. Relationship of herpes simplex virus genome configuration to productive and persistent infections. Proc Natl Acad Sci U S A 2003; 100: 7871-6.

43.- Chen S, Mills L, Perry P, Riddle S, Wobig R, Lown R, et al. Transactivation of the major capsid protein gene of herpes simplex virus type 1 requires a cellular transcription factor. J Virol 1992; 66: 4304-14.

44.- Rajcani J, Andrea V, Ingeborg R. Peculiarities of herpes simplex virus (HSV) transcription: an overview. Virus Genes 2004; 28: 293-310.

45.- Granzow H, Klupp B G, Fuchs W, Veits J, Osterrieder N, Mettenleiter T C. Egress of alphaherpesviruses: comparative ultrastructural study. J Virol 2001; 75: 3675-84.

46.- Johnson D C, Baines J D. Herpesviruses remodel host membranes for virus egress. Nat Rev Microbiol 2011; 9: 382-94

47.- Nii S, Morgan C, Rose H M. Electron microscopy of herpes simplex virus. II. Sequence of development. J Virol 1968; 2: 51736.

48.- Darlington R W, Moss L H, 3rd. Herpesvirus envelopment. J Virol 1968; 2: 48-55.

49.- Turcotte S, Letellier J, Lippe R. Herpes simplex virus type 1 capsids transit by the trans-Golgi network, where viral glycoproteins accumulate independently of capsid egress. J Virol 2005; 79: 8847-60.

50.- Johnson D C, Webb M, Wisner T W, Brunetti C. Herpes simplex virus $\mathrm{gE} / \mathrm{gI}$ sorts nascent virions to epithelial cell junctions, promoting virus spread. J Virol 2001; 75: 821-33.

51.- Aubert M, Yoon M, Sloan D D, Spear P G, Jerome K R. The virological synapse facilitates herpes simplex virus entry into T cells. J Virol
2009; 83: 6171-83

52.- Lubinski J M, Lazear H M, Awasthi S, Wang F, Friedman H M. The herpes simplex virus 1 IgG Fc receptor blocks antibodymediated complement activation and antibodydependent cellular cytotoxicity in vivo. J Virol 2011; 85: 3239-49.

53.- Hook L M, Lubinski J M, Jiang M, Pangburn M K, Friedman H M. Herpes simplex virus type 1 and 2 glycoprotein $\mathrm{C}$ prevents complement-mediated neutralization induced by natural immunoglobulin $\mathrm{M}$ antibody. J Virol 2006; 80: 4038-46.

54.- Corey L, Spear P G. Infections with herpes simplex viruses 1. N Engl J Med 1986; 314 686-91.

55.- Obara Y, Furuta Y, Takasu T, Suzuki S, Suzuki H, Matsukawa S, et al. Distribution of herpes simplex virus types 1 and 2 genomes in human spinal ganglia studied by PCR and in situ hybridization. J Med Virol 1997; 52: 136-42.

56.- Pevenstein S R, Williams R K, McChesney D, Mont E K, Smialek J E, Straus S E. Quantitation of latent varicella-zoster virus and herpes simplex virus genomes in human trigeminal ganglia. J Virol 1999; 73: 10514-8.

57.- Stevens J G, Cook M L. Latent herpes simplex virus in spinal ganglia of mice. Science 1971; 173: 843-5.

58.- Antinone S E, Smith G A. Retrograde axon transport of herpes simplex virus and pseudorabies virus: a live-cell comparative analysis. J Virol 2010; 84: 1504-12.

59.- Mellerick D M, Fraser N W. Physical state of the latent herpes simplex virus genome in a mouse model system: evidence suggesting an episomal state. Virology 1987; 158: 265-75.

60.- Goins W F, Wolfe D, Krisky D M, Bai Q, Burton E A, Fink D J, et al. Delivery using herpes simplex virus: an overview. Methods Mol Biol 2004; 246: 257-99.

61.- Stevens J G, Wagner E K, Devi-Rao G B, Cook M L, Feldman L T. RNA complementary to a herpesvirus alpha gene mRNA is prominen in latently infected neurons. Science 1987; 235: 1056-9.

62.- Umbach J L, Kramer M F, Jurak I, Karnowski H W, Coen D M, Cullen B R. MicroRNAs expressed by herpes simplex virus 1 during latent infection regulate viral mRNAs. Nature 2008; 454: 780-3.

63.- Kenny J J, Krebs F C, Hartle H T, Gartner A E, Chatton B, Leiden J M, et al. Identification of a second ATF/CREB-like element in the herpes simplex virus type 1 (HSV-1) latency-associated transcript (LAT) promoter. Virology 1994; 200 : 220-35.

64.- Oh J, Fraser N W. Temporal association of the herpes simplex virus genome with histone proteins during a lytic infection. J Virol 2008; 82: 3530-7.

65.- Huang J, Kent J R, Placek B, Whelan K A, 
Hollow C M, Zeng P Y, et al. Trimethylation of histone $\mathrm{H} 3$ lysine 4 by Set1 in the lytic infection of human herpes simplex virus 1. J Virol 2006; 80: 5740-6.

66.- Cliffe A R, Knipe D M. Herpes simplex virus ICP0 promotes both histone removal and acetylation on viral DNA during lytic infection. J Virol 2008; 82: 12030-8.

67.- Hobbs W E, 2nd, DeLuca N A. Perturbation of cell cycle progression and cellular gene expression as a function of herpes simplex virus ICP0. J Virol 1999; 73: 8245-55.

68.- Du T, Zhou G, Roizman B. Induction of apoptosis accelerates reactivation of latent HSV1 in ganglionic organ cultures and replication in cell cultures. Proc Natl Acad Sci U S A 2012; 109: 14616-21.

69.- Kobayashi M, Wilson A C, Chao M V, Mohr I. Control of viral latency in neurons by axonal mTOR signaling and the 4E-BP translation repressor. Genes Dev 2012; 26: 1527-32.

70.- Spruance S L. Cutaneous herpes simplex virus lesions induced by ultraviolet radiation. A review of model systems and prophylactic therapy with oral acyclovir. Am J Med 1988; 85: 43-5.

71.- Huang W, Xie P, Xu M, Li P, Zao G. The influence of stress factors on the reactivation of latent herpes simplex virus type 1 in infected mice. Cell Biochem Biophys 2011; 61: 115-22.

72.- Lautenschlager S, Eichmann A. The heterogeneous clinical spectrum of genital herpes. Dermatology 2001; 202: 211-9.

73.- Wald A, Zeh J, Selke S, Warren T, Ryncarz A J, Ashley R, et al. Reactivation of genital herpes simplex virus type 2 infection in asymptomatic seropositive persons. N Engl J Med 2000; 342: 844-50.

74.- Mertz G J, Benedetti J, Ashley R, Selke S A, Corey L. Risk factors for the sexual transmission of genital herpes. Ann Intern Med 1992; 116: 197-202.

75.- Fleming D T, McQuillan G M, Johnson R E, Nahmias A J, Aral S O, Lee F K, et al. Herpes simplex virus type 2 in the United States, 1976 to 1994. N Engl J Med 1997; 337: 1105-11.

76.- Cowan F M, Johnson A M, Ashley R, Corey L, Mindel A. Antibody to herpes simplex virus type 2 as serological marker of sexual lifestyle in populations. BMJ 1994; 309: 1325-9.

77.- Solomon L, Cannon M J, Reyes M, Graber J M, Wetherall N T, Reeves W C, et al. Epidemiology of recurrent genital herpes simplex virus types 1 and 2. Sex Transm Infect 2003; 79: 456-9.

78.- Janier M, Scieux C, Meouchi R, Tournoux C, Porcher R, Maillard A, et al. Virological, serological and epidemiological study of 255 consecutive cases of genital herpes in a sexually transmitted disease clinic of Paris (France): a prospective study. Int J STD AIDS 2006; 17: 44-9.

79.- Benedetti J, Corey L, Ashley R. Recurrence rates in genital herpes after symptomatic firstepisode infection. Ann Intern Med 1994; 121 : 847-54.

80.- Margolis T P, Imai Y, Yang L, Vallas V, Krause P R. Herpes simplex virus type 2 (HSV2) establishes latent infection in a different population of ganglionic neurons than HSV-1: role of latency-associated transcripts. J Virol 2007; 81: 1872-8.

81.- Ashkar A A, Yao X D, Gill N, Sajic D Patrick A J, Rosenthal KL. Toll-like receptor (TLR)-3, but not TLR4, agonist protects against genital herpes infection in the absence of inflammation seen with CpG DNA. J Infect Dis 2004; 190: 1841-9.

82.- Miller R L, Imbertson L M, Reiter M J, Gerster J F. Treatment of primary herpes simplex virus infection in guinea pigs by imiquimod. Antiviral Res 1999; 44: 31-42.

83.- Harandi A M, Eriksson K, Holmgren J. A protective role of locally administered immunostimulatory $\mathrm{CpG}$ oligodeoxynucleotide in a mouse model of genital herpes infection. $\mathrm{J}$ Virol 2003; 77: 953-62.

84.- Pyles R B, Higgins D, Chalk C, Zalar A, Eiden J, Brown C, et al. Use of immunostimulatory sequence-containing oligonucleotides as topical therapy for genital herpes simplex virus type 2 infection. J Virol 2002; 76: 11387-96.

85.- Theofilopoulos A N, Baccala R, Beutler B, Kono D H. Type I interferons (alpha/beta) in immunity and autoimmunity. Annu Rev Immunol 2005; 23: 307-36.

86.- Al-khatib K, Williams B R G, Robert H, Halford W, Carr D J J. Distinctive roles for 2',5'-oligoadenylate synthetases and doublestranded RNA-dependent protein kinase $\mathrm{R}$ in the in vivo antiviral effect of an adenoviral vector expressing murine IFN- $\beta$. JImmunol 2004; 172 5638-47.

87.- Alexopoulou L, Holt A C, Medzhitov R, Flavell R A. Recognition of double-stranded RNA and activation of NF-kappaB by Toll-like receptor 3. Nature 2001; 413: 732-8.

88.- Diebold S S, Kaisho T, Hemmi H, Akira S, Reis e Sousa C. Innate antiviral responses by means of TLR7-mediated recognition of singlestranded RNA. Science 2004; 303: 1529-31.

89.- Hemmi H, Kaisho T, Takeuchi O, Sato S, Sanjo H, Hoshino K, et al. Small anti-viral compounds activate immune cells via the TLR7 MyD88-dependent signaling pathway. Nat Immunol 2002; 3: 196-200.

90.- Shu M, Taddeo B, Zhang W, Roizman B. Selective degradation of mRNAs by the HSV host shutoff RNase is regulated by the UL47 tegument protein. Proc Natl Acad Sci U S A 2013; 110: E1669-75.

91.- Everly D N Jr, Read G S. Mutational analysis of the virion host shutoff gene (UL41) of herpes simplex virus (HSV): characterization of HSV type 1 (HSV-1)/HSV-2 chimeras. J Virol 1997; 71: 7157-66.

92.- Yao X D, Rosenthal K L. Herpes simplex virus type 2 virion host shutoff protein suppresses innate dsRNA antiviral pathways in human vaginal epithelial cells. J Gen Virol 2011; 92: 1981-93.

93.- Peng T, Zhu J, Klock A, Phasouk K, Huang M L, Koelle D M, et al. Evasion of the mucosal innate immune system by herpes simplex virus type 2. J Virol 2009; 83: 1255968.

94.- Johnson K E, Song B, Knipe D M. Role for herpes simplex virus 1 ICP27 in the inhibition of type I interferon signaling. Virology 2008; 374: 487-94.

95.- Shupack J, Stiller M, Davis I, Kenny C, Jondreau L. Topical alpha-interferon ointment with dimethyl sulfoxide in the treatment of recurrent genital herpes simplex. Dermatology 1992; 184: 40-4.

96.- Hirokawa D, Woldow A, Lee S N, Samie F. Treatment of recalcitrant herpes simplex virus with topical imiquimod. Cutis 2011; 88: 276-7.

97.- Kan Y, Okabayashi T, Yokota S, Yamamoto S, Fujii N, Yamashita T. Imiquimod suppresses propagation of herpes simplex virus 1 by upregulation of cystatin A via the adenosine receptor A1 pathway. J Virol 2012; 86: 1033846.

98.- Lascaux A S, Caumes E, Deback C, Melica G, Challine D, Agut H, et al. Successful treatment of aciclovir and foscarnet resistant Herpes simplex virus lesions with topical imiquimod in patients infected with human immunodeficiency virus type 1. J Med Virol 2012; 84: 194-7.

99.- Carr D J J, Tomanek L, Silverman R H, Iain L, Williams B R G, Campbell IL. RNA-dependent protein kinase is required for alpha-1 interferon transgene-induced resistance to genital herpes simplex virus type 2. J Virol 2005; 79: 9341-5.

100.-Leib D A, Machalek M A, Williams B R, Silverman R H, Virgin H W. Specific phenotypic restoration of an attenuated virus by knockout of a host resistance gene. Proc Natl Acad Sci USA 2000; 97: 6097--101.

101.-He B, Gross M, Roizman B. The $\gamma 34.5$ protein of herpes simplex virus 1 complexes with protein phosphatase $1 \alpha$ to dephosphorylate the alpha subunit of the eukaryotic translation initiation factor 2 and preclude the shutoff of protein synthesis by double-stranded RNAactivated protein kinase. Proc Natl Acad Sci U S A 1997; 94: 843-8.

102.-Poppers J, Mulvey M, Khoo D, Mohr I. Inhibition of PKR activation by the proline-rich RNA binding domain of the herpes simplex virus type 1 Us11 protein. J Virol 2000; 74: 11215-21.

103.-Fakioglu E, Wilson S S, Mesquita P M, Hazrati E, Cheshenko N, Blaho J A, et al. Herpes simplex virus downregulates secretory 
leukocyte protease inhibitor: a novel immune evasion mechanism. J Virol 2008; 82: 9337-44.

104.-Nguyen M L, Blaho J A. Apoptosis during herpes simplex virus infection. Adv Virus Res 2007; 69: 67-97.

105.-Morton E R, Blaho J A. Herpes simplex virus blocks Fas-mediated apoptosis independent of viral activation of NF-kappaB in human epithelial HEp-2 cells. J Interferon Cytokine Res 2007; 27: 365-76.

106.-Aubert M, Krantz E M, Jerome K R. Herpes simplex virus genes Us3, Us5, and Us12 differentially regulate cytotoxic $\mathrm{T}$ lymphocyteinduced cytotoxicity. Viral Immunol 2006; 19: 391-408.

107.-Zhou G, Galvan V, Campadelli-Fiume G, Roizman B. Glycoprotein D or J delivered in trans blocks apoptosis in SK-N-SH cells induced by a herpes simplex virus 1 mutant lacking intact genes expressing both glycoproteins. J Virol 2000; 74: 11782-91.

108.-Yamauchi Y, Daikoku T, Goshima F, Nishiyama Y. Herpes simplex virus UL14 protein blocks apoptosis. Microbiol Immunol 2003; 47: 685-9.

109.-Golembewski E K, Wales S Q, Aurelian L, Yarowsky P J. The HSV-2 protein ICP10PK prevents neuronal apoptosis and loss of function in an in vivo model of neurodegeneration associated with glutamate excitotoxicity. Exp Neurol 2007; 203: 381-93.

110.-Lubinski J M, Jiang M, Hook L, Chang Y, Sarver C, Mastellos D, et al. Herpes simplex virus type 1 evades the effects of antibody and complement in vivo. J Virol 2002; 76: 9232-41.

111.-Godfrey D I, Pellicci D G, Patel O, Kjer-Nielsen L, McCluskey J, Rossjohn J. Antigen recognition by CD1d-restricted NKT T cell receptors. Semin Immunol 2010; 22: 61-7.

112.-Rao P, Pham HT, Kulkarni A, Yang Y, Liu X, Knipe D M, et al. Herpes simplex virus 1 glycoprotein B and US3 collaborate to inhibit CD1d antigen presentation and NKT cell function. J Virol 2011; 85: 8093-104.

113.- Yuan W, Dasgupta A, Cresswell P. Herpes simplex virus evades natural killer T cell recognition by suppressing CD1d recycling. Nat Immunol 2006; 7: 835-42.

114.-Puttur F K, Fernández M A, White R, Roediger B, Cunningham A L, Weninger W, et al. Herpes simplex virus infects skin $\gamma \delta \mathrm{T}$ cells before Langerhans cells and impedes migration of infected Langerhans cells by inducing apoptosis and blocking E-cadherin downregulation. J Immunol 2010; 185: 477-87.

115.-Kim J O, Cha H R, Kim E D, Kweon M N. Pathological effect of IL-17A-producing TCRgammadelta $(+) \mathrm{T}$ cells in mouse genital mucosa against HSV-2 infection. Immunol Lett 2012; 147: 34-40.

116.-Iannello A, Debbeche O, El Arabi R, Samarani S, Hamel D, Rozenberg F, et al.
Herpes simplex virus type 1-induced FasL expression in human monocytic cells and its implications for cell death, viral replication, and immune evasion. Viral Immunol 2011; 24: 11-26.

117.-Schepis D, D'Amato M, Studahl M, Bergstrom T, Karre K, Berg L. Herpes simplex virus infection downmodulates NKG2D ligand expression. Scand J Immunol 2009; 69: 429-36.

118.- Tomazin R, Hill A, Jugovic P, York I, Van Endert P, Ploegh H, et al. Stable binding of the herpes simplex virus ICP47 protein to the peptide binding site of TAP. EMBO J 1996; 15 : 3256.

119.-Halford W P, Maender J L, Gebhardt B M. Re-evaluating the role of natural killer cells in innate resistance to herpes simplex virus type 1 . Virol J 2005; 2: 56

120.-Nandakumar S, Woolard S N, Yuan D, Rouse B T, Kumaraguru U. Natural killer cells as novel helpers in anti-herpes simplex virus immune response. J Virol 2008; 82: 10820-31.

121.-Para M F, Goldstein L, Spear P G. Similarities and differences in the Fc-binding glycoprotein ( $\mathrm{gE}$ ) of herpes simplex virus types 1 and 2 and tentative mapping of the viral gene for this glycoprotein. J Virol 1982; 41: 137-44.

122.-Armour K L, Atherton A, Williamson L M, Clark M R. The contrasting IgG-binding interactions of human and herpes simplex virus Fc receptors. Biochem Soc Trans 2002; 30: 495500

123.-Dilillo D J, Tan G S, Palese P, Ravetch J V. Broadly neutralizing hemagglutinin stalkspecific antibodies require $\mathrm{F} \gamma \mathrm{R}$ interactions for protection against influenza virus in vivo. Nat Med 2014; 20: 143-51.

124.-Carreno L J, González P A, Bueno S M, Riedel C A, Kalergis A M. Modulation of the dendritic cell-T-cell synapse to promote pathogen immunity and prevent autoimmunity. Immunotherapy 2011; 3: 6-11.

125.-González P A, Prado C E, Leiva E D, Carreno L J, Bueno S M, Riedel C A, et al. Respiratory syncytial virus impairs $\mathrm{T}$ cell activation by preventing synapse assembly with dendritic cells. Proc Natl Acad Sci U S A 2008; 105: 14999-5004.

126.-Banchereau J, Briere F, Caux C, Davoust J, Lebecque S, Liu YJ, et al. Immunobiology of dendritic cells. Annu Rev Immunol 2000; 18: 767-811.

127.-González P A, Carreno L J, Figueroa C A, Kalergis A M. Modulation of immunological synapse by membrane-bound and soluble ligands. Cytokine Growth Factor Rev 2007; 18: 19-31.

128.-Tobar J A, González P A, Kalergis A M. Salmonella escape from antigen presentation can be overcome by targeting bacteria to Fc gamma receptors on dendritic cells. J Immunol 2004; 173: 4058-65.
129.- Tobar J A, Carreno L J, Bueno S M, González P A, Mora J E, Quezada S A, et al. Virulent Salmonella enterica serovar typhimurium evades adaptive immunity by preventing dendritic cells from activating $\mathrm{T}$ cells. Infect Immun 2006; 74: 6438-48.

130.-Raftery M J, Winau F, Kaufmann S H, Schaible U E, Schonrich G. CD1 antigen presentation by human dendritic cells as a target for herpes simplex virus immune evasion. J Immunol 2006; 177: 6207-14.

131.-Majumder B, Janket M L, Schafer E A, Schaubert K, Huang X L, Kan-Mitchell J, et al. Human immunodeficiency virus type $1 \mathrm{Vpr}$ impairs dendritic cell maturation and T-cell activation: implications for viral immune escape. J Virol 2005; 79: 7990-8003.

132.-Morrow G, Slobedman B, Cunningham AL, Abendroth A. Varicella-zoster virus productively infects mature dendritic cells and alters their immune function. J Virol 2003; 77: 4950-9.

133.-Bueno S M, González P A, Carreno L J, Tobar J A, Mora G C, Pereda C J, et al. The capacity of Salmonella to survive inside dendritic cells and prevent antigen presentation to $T$ cells is host specific. Immunology 2008; 124: 522-33.

134.-Bosnjak L, Miranda-Saksena M, Koelle D M, Boadle R A, Jones C A, Cunningham AL. Herpes simplex virus infection of human dendritic cells induces apoptosis and allows cross-presentation via uninfected dendritic cells. J Immunol 2005; 174: 2220-7.

135.-Stefanidou M, Ramos I, Mas Casullo V, Trepanier J B, Rosenbaum S, FernándezSesma A, et al. Herpes simplex virus 2 (HSV-2) prevents dendritic cell maturation, induces apoptosis, and triggers release of proinflammatory cytokines: potential links to HSV-HIV synergy. J Virol 2013; 87: 1443-53.

136.-Gobeil P A, Leib D A. Herpes simplex virus $\gamma 34.5$ interferes with autophagosome maturation and antigen presentation in dendritic cells. MBio 2012; 3: e00267-12.

137.-Yordy B, Iijima N, Huttner A, Leib D, Iwasaki A. A neuron-specific role for autophagy in antiviral defense against herpes simplex virus. Cell Host Microbe 2012; 12: 334-45.

138.-Hill A B, Barnett B C, McMichael A J, McGeoch D J. HLA class I molecules are not transported to the cell surface in cells infected with herpes simplex virus types 1 and 2 . JImmunol 1994; 152: 2736-41.

139.-Hill A, Jugovic P, York I, Russ G, Bennink J, Yewdell J, et al. Herpes simplex virus turns off the TAP to evade host immunity. Nature 1995; 375: 411-5.

140.-Imai T, Koyanagi N, Ogawa R, Shindo K, Suenaga T, Sato A, et al. Us3 kinase encoded by herpes simplex virus 1 mediates downregulation of cell surface major histocompatibility complex 
class I and evasion of CD8+ T cells. PLoS One 2013; 8: e72050.

141.-Elboim M, Grodzovski I, Djian E, Wolf D G, Mandelboim O. HSV-2 specifically down regulates HLA-C expression to render HSV2-infected DCs susceptible to NK cell killing. PLoS Pathog 2013; 9: e1003226.

142.-Jerome K R, Fox R, Chen Z, Sears A E, Lee H, Corey L. Herpes simplex virus inhibits apoptosis through the action of two genes, Us5 and Us3. J Virol 1999; 73: 8950-7.

143.-Vanden Oever M J, Han J Y. Caspase 9 is essential for herpes simplex virus type 2-induced apoptosis in T cells. J Virol 2010; 84: 3116-20.

144.-Jerome K R, Chen Z, Lang R, Torres M R, Hofmeister J, Smith S, et al. HSV and glycoprotein $\mathrm{J}$ inhibit caspase activation and apoptosis induced by granzyme B or Fas. J Immunol 2001; 167: 3928-35.

145.-Raftery M J, Behrens C K, Muller A, Krammer P H, Walczak H, Schonrich G. Herpes simplex virus type 1 infection of activated cytotoxic T cells: Induction of fratricide as a mechanism of viral immune evasion. J Exp Med 1999; 190: 1103-14.

146.-La S, Kim J, Kwon B S, Kwon B. Herpes simplex virus type 1 glycoprotein D inhibits T-cell proliferation. Mol Cells 2002; 14: 398403.

147.-Sloan D D, Han J Y, Sandifer T K, Stewart M, Hinz A J, Yoon M, et al. Inhibition of TCR signaling by herpes simplex virus. J Immunol 2006; 176: 1825-33.

148.-Cheung T C. Modulation of T cell proliferation through the LIGHT-HVEM-BTLA cosignaling pathway. Recent Pat DNA Gene Seq 2009; 3 : 177-82.

149.-Fernández M A, Puttur F K, Wang Y M, Howden W, Alexander S I, Jones C A. T regulatory cells contribute to the attenuated primary $\mathrm{CD} 8^{+}$and $\mathrm{CD} 4^{+} \mathrm{T}$ cell responses to herpes simplex virus type 2 in neonatal mice. J Immunol 2008; 180: 1556-64.

150.-Suvas S, Kumaraguru U, Pack CD, Lee S, Rouse B T. $\mathrm{CD}^{+} \mathrm{CD} 25^{+} \mathrm{T}$ cells regulate virusspecific primary and memory $\mathrm{CD} 8^{+} \mathrm{T}$ cell responses. J Exp Med 2003; 198: 889-901.
151.-Fernández M A, Yu U, Zhang G, White R, Sparwasser T, Alexander S I, et al. Treg depletion attenuates the severity of skin disease from ganglionic spread after HSV-2 flank infection. Virology 2013; 447: 9-20.

152.-Iyer A V, Pahar B, Chouljenko V N, Walker J D, Stanfield B, Kousoulas K G. Single dose of Glycoprotein K (gK)-deleted HSV-1 liveattenuated virus protects mice against lethal vaginal challenge with HSV-1 and HSV-2 and induces lasting $\mathrm{T}$ cell memory immune responses. Virol J 2013; 10: 317.

153.-Lund J M, Hsing L, Pham T T, Rudensky A Y. Coordination of early protective immunity to viral infection by regulatory T cells. Science 2008; 320: 1220-4.

154.-Burchett S K, Corey L, Mohan K M, Westall J, Ashley R, Wilson CB. Diminished interferongamma and lymphocyte proliferation in neonatal and postpartum primary herpes simplex virus infection. J Infect Dis 1992; 165: 813-8.

155.-Evans I A, Jones C A. HSV induces an early primary $\mathrm{Th} 1 \mathrm{CD} 4 \mathrm{~T}$ cell response in neonatal mice, but reduced CTL activity at the time of the peak adult response. Eur J Immunol 2005; 35: 1454-62.

156.-Awasthi S, Friedman H M. Status of prophylactic and therapeutic genital herpes vaccines. Curr Opin Virol 2014; 6C: 6-12.

157.-Bernstein D I, Aoki F Y, Tyring S K, Stanberry L R, St-Pierre C, Shafran S D, et al. Safety and immunogenicity of glycoprotein D-adjuvant genital herpes vaccine. Clin Infect Dis 2005; 40: 1271-81.

158.-Johnston C, Koelle D M, Wald A. Current status and prospects for development of an HSV vaccine. Vaccine 2014; 32: 1553-60.

159.-Belshe R B, Leone P A, Bernstein D I, Wald A, Levin M J, Stapleton J T, et al. Efficacy results of a trial of a herpes simplex vaccine. N Engl $\mathrm{J}$ Med 2012; 366: 34-43.

160.-Gershon A A. Varicella zoster vaccines and their implications for development of HSV vaccines. Virology 2013; 435: 29-36.

161.-Goldman G S, King P G. Review of the United States universal varicella vaccination program: Herpes zoster incidence rates, cost-effectiveness, and vaccine efficacy based primarily on the antelope valley varicella active surveillance project data. Vaccine 2013; 31: 1680-94.

162.-de Bruyn G, Vargas-Cortez M, Warren T, Tyring S K, Fife K H, Lalezari J, et al. A randomized controlled trial of a replication defective ( $\mathrm{gH}$ deletion) herpes simplex virus vaccine for the treatment of recurrent genital herpes among immunocompetent subjects. Vaccine 2006; 24: 914-20.

163.-Casanova G, Cancela R, Alonzo L, Benuto R. A double-blind study of the efficacy and safety of the ICP10PK vaccine against recurrent genital HSV-2 infections. Cutis 2002.

164.-Halford W P, Puschel R, Gershburg E, Wilber A, Gershburg S, Rakowski B. A liveattenuated HSV-2 ICP0 virus elicits 10 to 100 times greater protection against genital herpes than a glycoprotein D subunit vaccine. PLoS One 2011; 6: e17748.

165.-Da Costa X, Kramer M F, Zhu J, Brockman M A, Knipe D M. Construction, phenotypic analysis, and immunogenicity of a UL5/UL29 double deletion mutant of herpes simplex virus 2. J Virol 2000; 74: 7963-71.

166.-Mundle S T, Hernández H, Hamberger J, Catalan J, Zhou C, Stegalkina S, et al. Highpurity preparation of HSV-2 vaccine candidate ACAM529 is immunogenic and efficacious in vivo. PLoS One 2013; 8: e57224.

167.-Awasthi S, Zumbrun E E, Si H, Wang F, Shaw C E, Cai M, et al. Live attenuated herpes simplex virus 2 glycoprotein E deletion mutant as a vaccine candidate defective in neuronal spread. J Virol 2012; 86: 4586-98.

168.-Kolb A W, Ane C, Brandt C R. Using HSV-1 Genome phylogenetics to track past human migrations. PLoS One 2013; 8: e76267.

169.-Awasthi S, Lubinski J M, Shaw C E, Barrett S M, Cai M, Wang F, et al. Immunization with a vaccine combining herpes simplex virus 2 (HSV-2) glycoprotein C (gC) and $\mathrm{gD}$ subunits improves the protection of dorsal root ganglia in mice and reduces the frequency of recurrent vaginal shedding of HSV-2 DNA in guinea pigs compared to immunization with $\mathrm{gD}$ alone. J Virol 2011; 85: 10472-86. 